\title{
Nature monitoring: a tool for the evaluation of the preservation of synanthropic habitats
}

\author{
Anna Bomanowska ${ }^{1 *} \&$ Izabella Kirpluk $^{2}$
}

${ }^{1}$ Department of Geobotany and Plant Ecology, Faculty of Biology and Environmental Protection, University of Łódź, Banacha 12/16, 90237 Łódź, Poland

${ }^{2}$ Botanic Garden, Faculty of Biology, University of Warsaw, Al. Ujazdowskie 4, 00-478 Warsaw, Poland

"corresponding author: (e-mail: knopikaa@biol.uni.lodz.pl)

\begin{abstract}
The article presents the results of nature monitoring in synanthropic habitats. It shows the organizational aspects of monitoring, a survey procedure, including its assessment for use in synanthropic habitats, and the key findings of the research, including the evaluation of the conservation status of habitats covered by the monitoring and influencing factors' effects. Observations of segetal and ruderal habitats were carried out in 2013 within the Kampinos National Park, according to the recommendations specified in the State Environmental Monitoring Programme, with specific adjustment to the monitored habitats. We used, for example, modified indices for specific structures and functions, e.g., by introducing the index of "archaeophytes", which was also adopted as a cardinal index for synanthropic habitats. The obtained results show the detailed information, collected during monitoring, on the current status of synanthropic habitats. They allowed to evaluate conservation status, threats and conservation prospects for these habitats. This is the first proposal for the standardized monitoring of synanthropic habitats in Poland.
\end{abstract}

Key words: biodiversity monitoring, conservation management, methodological framework, low-intensity agriculture, protected area, rural areas, synanthropic communities, Kampinos National Park

\section{Introduction}

Monitoring can be defined as the collection and analysis of repetitive observations or measurements of a specified set of variables over an extended period of time to evaluate the changes in habitat condition and progress towards meeting a management objective (Elzinga et al. 1998). One important kind of monitoring is nature monitoring, i.e., regular observations and measurements of selected biotic elements of nature (species, habitats, ecosystems), conducted to obtain information on changes occurring in them at a specific time, and on the directions and rates of these changes (Vaughan et al. 2001; Yoccoz et al. 2001). The monitoring of nature is an integral part of efforts to stop the loss of biodiversity (Beever 2006; Pereira \& Cooper 2006). The evaluation of nature elements provides guidelines for making decisions on how to maintain biological diversity, especially for planning efficient conservation activities (Niemelä 2000; Buckland et al. 2005; Stem et al. 2005; Nichols \& Williams 2006; Henry et al. 2008). The monitoring of a biological system is needed before active management, to improve the biological understanding on which such management can be based (Nichols \& Williams 2006). This results in different conceptual frameworks and recommendations for the development and maintenance of effective ecological monitoring programmes (e.g. Vos et al. 2000; Yoccoz et al. 2001; Parr et al. 2002; Weber et al. 2004; Green et al. 2005; Legg \& Nagy 2006; Teder et al. 2007). However, monitoring programmes are more than just data collection. They also involve all other activities needed to present the results, including, e.g., analysis and interpretation of data (Vos et al. 2000; Yoccoz et al. 2001).

The obligation to implement nature monitoring is imposed by international conventions, in particular the Convention on Biodiversity (CBD 1992). Pursuant to Article $7 \mathrm{~b}$, countries contracted to the Convention are obliged to identify and monitor their biodiversity. Tasks implemented under nature monitoring also result from the European Union directives, mainly Council Directive 92/43/EEC on the conservation of natural 
habitats and wild fauna and flora (Habitats Directive), especially Annex II, species requiring designation of Special Areas of Conservation (Council of the European Communities 1992), and Council Directive 2009/147/ EC on the conservation of wild birds (Birds Directive; European Commission 1979). International legislation compels national governments to implement monitoring programmes for biological diversity (e.g. Critchley et al. 2003; Weber et al. 2004; Lengyel et al. 2008; Cierlik 2010).

In Poland the obligation to carry out nature monitoring is imposed by the Nature Conservation Act (Journal of Laws of 2004, No. 92, item 880 with later amendments). Nature monitoring is a part of The State Environmental Monitoring Programme, established pursuant to the Act of 20 June 1991 on Inspection for Environmental Protection (Journal of Laws of 2007 No. 44 , item 287 , as amended).

Because of the requirements under EU law, the monitoring should, above all, enable the assessment of the nature conservation status of natural habitats and species of European Community importance, and help to evaluate the effectiveness of measures applied to protect them (Ostermann 1998). In keeping with this, since 2006, under The State Environmental Monitoring Programme, the task "Monitoring of natural habitats and species with particular attention to special areas of conservation of habitats of the Natura 2000" has been accomplished. The aim of this programme is to provide information enabling the evaluation of the conservation status of habitats and species at the national level (Natura 2000 sites), to indicate conservation measures, and to assess the efficiency of these measures (Cierlik 2010). Methodological and organizational principles for the monitoring of species and natural habitats were established, and monitoring was carried out for all types of natural habitats occurring in Poland, listed in Annex I to the Habitats Directive (81 types), and species listed in Annexes II, IV and V of the Habitats Directive, including 140 animal species and 54 taxa of plants (Makomaska-Juchiewicz 2010; MakomaskaJuchiewicz \& Baran 2012a, 2012b; Mróz 2010, 2012a, 2012b; Perzanowska 2010, 2012a, 2012b).

From the viewpoint of the needs of nature protection in Poland, the scope of monitoring should be broader and also cover other habitats and species that are endangered but not listed in the annexes to the Habitats Directive. This concerns such habitats as synanthropic communities and species, which are today undergoing rapid and irreversible changes due to human activity (Ratyńska \& Boratyński 2000; Brzeg \& Wojterska 2001; Stoate et al. 2001; Bomanowska 2010; Siciński \& Sieradzki 2010; Storkey et al. 2012; Zając \& Zając 2014). So far, monitoring has not been carried out in such habitats due to their specific, highly anthropogenic character and, associated with this, the common perception of their low value for nature, as well as due to their location on private land and, thus, limited access, as researchers need owners' permission each time to enter the property.

An opportunity to implement this in practice emerged in 2013, when the Kampinos National Park (KNP) commissioned the development of methodology and monitoring of two types of synanthropic habitats within the park's area, i.e. segetal and ruderal communities. A multifaceted environmental monitoring in national parks is a necessary element of effective management of natural resources and their conservation, but is also a tool for the analysis of changes that occur in these parks. This is why it should cover all types of habitats within a given national park (e.g. Andrzejewska 2003; Karwowski 2003; Knapik \& Raj 2014).

The article presents the scope and organizational aspects of nature monitoring in the synanthropic habitats of KNP, a research procedure, including its assessment for use in synanthropic habitats, and the key findings from the carried out monitoring, including the evaluation of the conservation status of habitats covered by the monitoring, and evaluation of influencing factors' effects.

\section{Material and methods}

\subsection{Study area}

The Kampinos National Park ( $\left.52^{\circ} 19^{\prime} 0^{\prime \prime} \mathrm{N}, 20^{\circ} 34^{\prime} 0^{\prime \prime} \mathrm{E}\right)$ was established in 1959 to protect the natural values and historic and cultural heritage of Kampinos Forest. The park covers an area of 38544.33 ha and is located in Central Poland, in the south-western part of the Warsaw Basin mesoregion, between the left bank of the Vistula and Bzura, just off the north-western outskirts of Warsaw (Fig. 1a). The aim of nature protection is to preserve a complex of glacial valley inland dunes and swamps unique in Poland and Europe, with their biological and landscape diversity (Andrzejewska 2003). Due to their natural and cultural significance, in 2000, the KNP and its buffer zone were designated the "Kampinos Forest" Biosphere Reserve by UNESCO. Since 2004, the KNP has also been a NATURA 2000 site (code PLC 140001), because of the abundance of bird species and the diversity of plant communities.

A specific feature of KNP is its developed network of settlements and the presence of agricultural areas. They were established in clearings within the forest complex as a result of settlement in the $18^{\text {th }}-20^{\text {th }}$ centuries (Kębłowska 2009). Settlements and agricultural land cover in total 7762 ha, which is $20.1 \%$ of the park's surface area. Rural areas and agricultural land are linked with two types of synanthropic vegetation: segetal weed communities associated with cereals or root crops, 


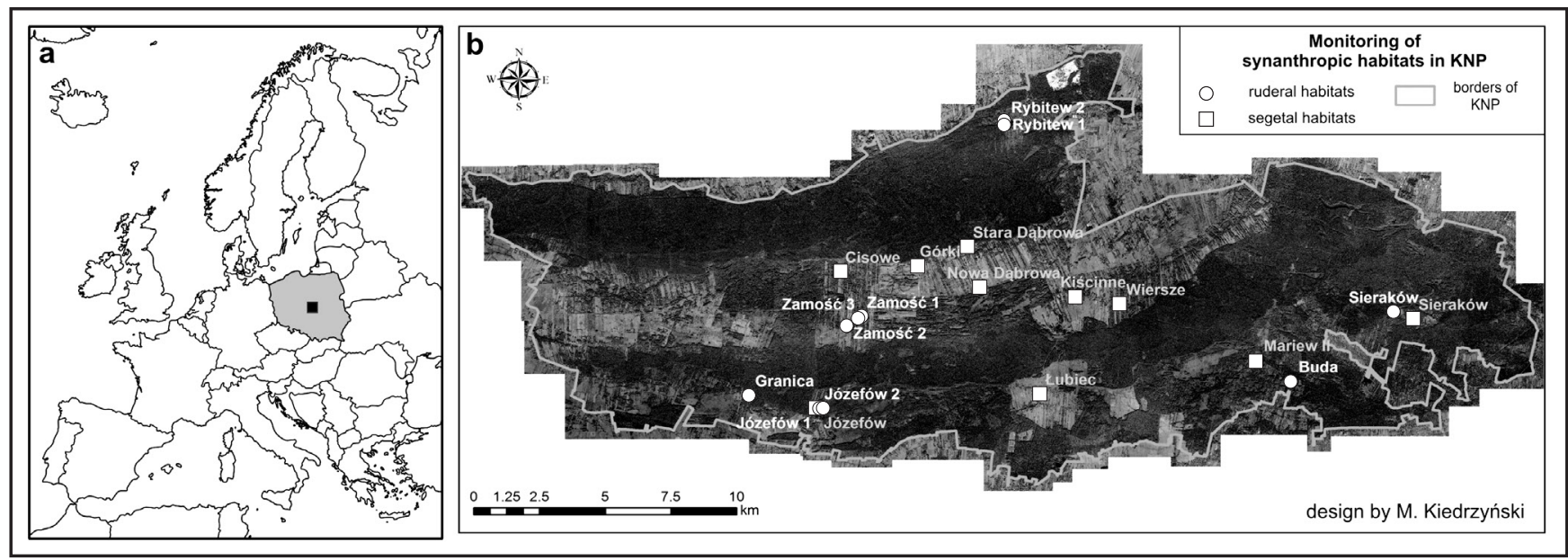

Fig. 1. Location of the Kampinos National Park (a), the monitoring locations for synanthropic habitats (b) Explanations: gray dots - ruderal sites, gray squares - segetal sites

and ruderal - plant communities near houses and fences, on roadsides, cottage yards, rubbish heaps, developed land and in abandoned homesteads, etc. The persistence of synanthropic habitats is determined by continuous, moderate anthropogenic pressure. However, since the establishment of KNP, the abandonment of fields and the depopulation of villages continues, while former farm buildings are demolished and arable fields afforested or left to undergo secondary succession (Markowski 2009). Because of these processes, synanthropic habitats are disappearing from the landscape of Kampinos Forest, along with many valuable and rare plant species (Kirpluk 2005, 2009, 2011; Bomanowska 2006, 2009; Kirpluk \& Bomanowska 2008).

\subsection{Selection and description of monitoring locations}

Based on orthophoto maps, maps of actual vegetation, analyses of source materials, but above all based on field pilot research, 10 sites were chosen for each of the two types of synanthropic habitats, where in 2013, monitoring plots were established and observations carried out (Fig. 1b). Selection criteria included local edaphic diversity and a good reflection of the ecological transformations that occurred in the habitat.

Monitoring locations were relatively uniform areas of the examined habitat, clearly demarcated and easy to describe in the field (Mróz 2010, 2012a, 2012b). For segetal habitats the demarcation of a monitoring location was easy because weed communities are closely linked with crops and limited to a specific arable field. Thus, a monitoring location was defined as a single arable field with a specific crop. The site of a ruderal habitat was defined as a group of well-distinguished patches covering, for example, the yard of a single farm, land near a house or fence on a single farm, or a roadside in a single village. The surface area of the habitat on a given site was the sum of the patches' area (3 patches as standard), where phytosociological relevé samples were taken. The size of the monitoring locations was diverse.

\subsection{Methods of monitoring research}

The carried out monitoring of synanthropic habitats was a part of the task entitled "The monitoring of plant communities", conducted by the KNP under the programme "Inventory and monitoring of biotic natural resources in KNP, including natural habitats and species covered by Natura 2000" (contract with National Fund for Environmental Protection and Water Management no. $453 / 2011 / \mathrm{Wn}-50 / \mathrm{OP}-\mathrm{IN} / \mathrm{D})$.

The described habitat includes the communities of arable weeds from Stellarietea mediae class and communities of ruderal weeds from Sisymbrietalia order (Stellarietea mediae class) and Artemisienea subclass (Artemisietea class; Matuszkiewicz 2008). The habitat is not listed in "The guides of the Natura 2000 habitats and species conservation, a methodological textbook", but when preparing research methodology we followed the principles of the State Environmental Monitoring Programme (SEMP) contained in these guides (see Mróz 2010, 2012a, 2012b). The report on the carried out monitoring was also prepared based on the guidelines presented in these textbooks. Collected documentation material was systematized according to the Matuszkiewicz (2008) classification. Species nomenclature followed Mirek et al. (2002).

Observations were carried out according to the recommendations specified in the SEMP, with specific adjustment to the monitored habitats. Because of the specific character of the studied habitats, we did not demarcate the transect, but instead established 3 subsequent phytosociological relevés randomly or arbitrarily 
on each monitoring site. On segetal habitats, whenever possible, we maintained a linear arrangement of relevés and established them at the beginning, in the middle, and at the end of an arable field. In the case of ruderal

Table 1. Description and evaluation of parameters and indices of the specific structure of the habitat, as well as "conservation prospects" for segetal habitats in the Kampinos National Park (according to Bomanowska 2013a, amended)

\begin{tabular}{|c|c|c|c|c|}
\hline \multirow[b]{2}{*}{ Parameter/Index } & \multirow[b]{2}{*}{ Description } & \multicolumn{3}{|c|}{ Status } \\
\hline & & $\begin{array}{l}\text { Favourable } \\
\qquad(\mathrm{FV})\end{array}$ & $\begin{array}{l}\text { Unfavourable, } \\
\text { inadequate } \\
\text { (U1) }\end{array}$ & $\begin{array}{c}\text { Unfavourable, } \\
\text { bad (U2) }\end{array}$ \\
\hline $\begin{array}{l}\text { Parameter } \\
\text { "Surface area of } \\
\text { the habitat" }\end{array}$ & $\begin{array}{l}\text { An assessment of the changes in surface area (stable, } \\
\text { increases, decreases) occupied by the habitat and its } \\
\text { dynamics is required }\end{array}$ & $\begin{array}{l}\text { Does not } \\
\text { change or } \\
\text { increases }\end{array}$ & $\begin{array}{l}\text { A slight } \\
\text { decrease in the } \\
\text { habitat area in } \\
\text { comparison } \\
\text { with previous } \\
\text { studies or cited } \\
\text { in references }\end{array}$ & $\begin{array}{l}\text { An evident } \\
\text { decrease in the } \\
\text { habitat area in } \\
\text { comparison } \\
\text { with previous } \\
\text { studies or cited } \\
\text { in references }\end{array}$ \\
\hline \multicolumn{5}{|c|}{ Parameter "Specific structure and functions" } \\
\hline $\begin{array}{l}\text { Percentage } \\
\text { proportion of } \\
\text { the habitat in } \\
\text { the location }\end{array}$ & $\begin{array}{l}\text { Percentage of surface area occupied by habitat on the } \\
\text { location determined with an accuracy of } 10 \% \text {. This index } \\
\text { defines indirectly the spatial structure and the degree of } \\
\text { fragmentation of the habitat in the monitored location }\end{array}$ & $80 \%$ and more & $50-80 \%$ & $\begin{array}{l}\text { Up to max. } \\
50 \%\end{array}$ \\
\hline *Typical species & $\begin{array}{l}\text { This index describes the specific richness of species } \\
\text { composition in plant communities in the monitored location. } \\
\text { The typical species show great variability depending on } \\
\text { syntaxonomic and ecological diversity of the habitat. The } \\
\text { list of typical species for the habitat includes characteristic } \\
\text { and distinguishing species for the Centauretalia cyani order, } \\
\text { Aperion spicae-venti alliance and its lower syntaxonomic } \\
\text { units (communities of cereal weeds), and characteristic and } \\
\text { distinguishing species for Polygono-Chenopodietalia order, } \\
\text { Panico-Setarion and Polygono-Chenopodion alliances and } \\
\text { their lower syntaxonomic units (communities of root crop } \\
\text { weeds). A list of typical species with their approximate } \\
\text { percentage of coverage (with an accuracy of 10\%) in the } \\
\text { location should be given }\end{array}$ & $\begin{array}{l}\text { Numerous } \\
\text { species } \\
\text { (more than } \\
\text { 5) and with } \\
\text { significant } \\
\text { coverage (3 } \\
\text { or more on } \\
\text { the Braun- } \\
\text { Blanquet } \\
\text { scale) }\end{array}$ & $\begin{array}{l}\text { Less than } 5 \\
\text { species and } \\
\text { with low } \\
\text { coverage }\end{array}$ & $\begin{array}{l}\text { No typical } \\
\text { species or one } \\
\text { of them with } \\
\text { insignificant } \\
\text { coverage }\end{array}$ \\
\hline $\begin{array}{l}\text { Dominant } \\
\text { species }\end{array}$ & $\begin{array}{l}\text { This index describes the structure of plant communities in } \\
\text { the monitored location, as well as their conservation status } \\
\text { (or possibly the degree of their deformation). It answers the } \\
\text { question of whether the species characteristic of the habitat } \\
\text { dominate in the monitored location. The index describes } \\
\text { the presence of co-dominant and dominant species (score } \\
3 \text { or more on the Braun-Blanquet scale). The assessment } \\
\text { of the indicator is complex, and depends on the nature of } \\
\text { the dominants and the level of the domination, because a } \\
\text { high domination ratio is usually connected with low species } \\
\text { diversity. The presence of dominant species (score } 4-5 \text { on the } \\
\text { Braun-Blanquet scale), even those typical to the community, } \\
\text { results from negative changes in the community and should } \\
\text { decrease the index value. A list of species dominating in the } \\
\text { location and their approximate percentage coverage (with } \\
\text { an accuracy of } 10 \% \text { ) should be given. Only species with the } \\
\text { highest coverage in the location ( } \geq 10 \% \text { ) should be replaced }\end{array}$ & $\begin{array}{l}\text { No species } \\
\text { with coverage } \\
>50 \% \text {, co- } \\
\text { dominance of } \\
\text { species typical } \\
\text { for habitat }\end{array}$ & $\begin{array}{l}\text { Dominant } \\
\text { species are } \\
\text { present (with } \\
\text { coverage } \\
>50 \% \text { ), } \\
\text { dominance of } \\
\text { segetal species } \\
\text { characteristic } \\
\text { for Stellarietea } \\
\text { mediae class }\end{array}$ & $\begin{array}{l}\text { Among the } \\
\text { dominants } \\
\text { (with coverage } \\
>50 \% \text { ) } \\
\text { expansive } \\
\text { species or } \\
\text { ecologically } \\
\text { alien for } \\
\text { habitat species } \\
\text { are present }\end{array}$ \\
\hline *Archaeophytes & $\begin{array}{l}\text { Index describes the share of archaeophtes, e.g., alien species } \\
\text { established in Polish flora, which arrived in "ancient" times } \\
\text { (prior to 1492). Typically formed segetal communities are } \\
\text { characterised by a significant share of species from this } \\
\text { group. A reduced number of archaeophytes indicates the } \\
\text { degeneration of the community and reduces the index value. } \\
\text { A list of archaeophytes and their approximate percentage } \\
\text { coverage (with an accuracy of } 10 \% \text { ) should be given }\end{array}$ & $\begin{array}{l}\text { Numerous } \\
(\geq 10)\end{array}$ & Several $(5-10)$ & Few $(\leq 5)$ \\
\hline
\end{tabular}




\begin{tabular}{|c|c|c|c|c|}
\hline $\begin{array}{l}\text { Alien invasive } \\
\text { species }\end{array}$ & $\begin{array}{l}\text { This index describes the degree of deformation of the } \\
\text { habitat and share of geographically alien species considered } \\
\text { as invasive in Poland. Invasive species that, at the same } \\
\text { time, are species characteristic for associations and higher } \\
\text { phytosociological units representing the habitat should not } \\
\text { be considered unless their coverage is significant (more } \\
\text { than } 50 \% \text { ). The presence of even single individuals ("+" } \\
\text { on the Braun-Blanquet scale) representing invasive species } \\
\text { in a patch, with some exceptions specified earlier) should } \\
\text { be associated with reduced index value. A list of invasive } \\
\text { alien species should be given together with their percentage } \\
\text { proportions (with an accuracy of } 10 \% \text { ) }\end{array}$ & $\begin{array}{l}\text { No invasive } \\
\text { species and/ } \\
\text { or the total } \\
\text { coverage of } \\
\text { characteristic } \\
\text { (invasive) } \\
\text { species }<50 \%\end{array}$ & $\begin{array}{l}\text { Single } \\
\text { individuals } \\
\text { of invasive } \\
\text { species with a } \\
\text { total coverage } \\
<5 \% \text { or } \\
\text { coverage of } \\
\text { characteristic } \\
\text { (invasive) } \\
\text { species }<50 \%\end{array}$ & $\begin{array}{l}\text { Coverage } \\
\text { of invasive } \\
\text { species } \geq 5 \% \\
\text { and } / \text { or total } \\
\text { coverage of } \\
\text { characteristic } \\
\text { (invasive) } \\
\text { species } \geq 50 \%\end{array}$ \\
\hline $\begin{array}{l}\text { *Expansive } \\
\text { species of } \\
\text { herbaceous } \\
\text { plants }\end{array}$ & $\begin{array}{l}\text { List of native expansive herb species spreading in the habitat, } \\
\text { which can pose a threat to the habitat. For the described } \\
\text { habitat most of these species are typical, and, thus, they pose } \\
\text { a risk only if species coverage is } \geq 2 \text { on the Braun-Blanquet } \\
\text { scale. The index value should be reduced in such a case. } \\
\text { A list of expansive species in the location should be given } \\
\text { together with their percentage proportions (with an accuracy } \\
\text { of } 10 \% \text { ) }\end{array}$ & $\begin{array}{l}\text { Lack or } \\
\text { expansive } \\
\text { species with } \\
\text { low coverage } \\
(<10 \%)\end{array}$ & $\begin{array}{l}\text { Average } \\
\text { number of } \\
\text { expansive } \\
\text { species with } \\
\text { coverage up to } \\
30 \%\end{array}$ & $\begin{array}{l}\text { Numerous } \\
\text { expansive } \\
\text { species, with } \\
\text { a considerable } \\
\text { coverage } \\
(>50 \%)\end{array}$ \\
\hline $\begin{array}{l}\text { *Anthropogenic } \\
\text { pressure (level } \\
\text { of agricultural } \\
\text { technology) }\end{array}$ & $\begin{array}{l}\text { The index describes effects of the carried out agrotechnical } \\
\text { activities (techniques and intensity of soil preparation and } \\
\text { cultivation, including the use of nitrogen fertilizers and } \\
\text { chemical plant protection measures, use of qualified seed } \\
\text { material, mechanisation of field work) that affect the state of } \\
\text { the habitat. The index value is decreased because of the use } \\
\text { of nitrogen fertilizers and herbicides, because they disturb the } \\
\text { biocenotic balance, leading to changes in species composition } \\
\text { and structure of communities established during traditional } \\
\text { management. Index values are also reduced because of } \\
\text { strongly limited agrotechnical activities, e.g., simplified or } \\
\text { abandoned crop rotation }\end{array}$ & $\begin{array}{l}\text { Adequate } \\
\text { (traditional, } \\
\text { extensive } \\
\text { methods of } \\
\text { cultivation) }\end{array}$ & $\begin{array}{l}\text { Inadequate } \\
\text { (faulty, inferior } \\
\text { methods of } \\
\text { cultivation) }\end{array}$ & $\begin{array}{l}\text { Inadequate } \\
\text { (modern } \\
\text { techniques of } \\
\text { cultivation; } \\
\text { intensive use } \\
\text { of mineral } \\
\text { fertilizers and } \\
\text { herbicides) }\end{array}$ \\
\hline \multicolumn{2}{|c|}{ Assessment of Parameter "Specific structure and functions" } & $\begin{array}{l}\text { All cardinal } \\
\text { indices } \\
\text { evaluated as } \\
\text { FV, remaining } \\
\text { indices as at } \\
\text { least U1 }\end{array}$ & $\begin{array}{l}\text { One or more } \\
\text { cardinal } \\
\text { indices } \\
\text { evaluated as } \\
\text { U1 }\end{array}$ & $\begin{array}{l}\text { One or more } \\
\text { cardinal } \\
\text { indices } \\
\text { evaluated as } \\
\mathrm{U} 2\end{array}$ \\
\hline $\begin{array}{l}\text { Parameter } \\
\text { "Conservation } \\
\text { prospects of the } \\
\text { habitat" }\end{array}$ & $\begin{array}{l}\text { Assessment of realistic possibility for the maintenance of the } \\
\text { habitat in an appropriate state, its current conservation status } \\
\text { and factors that can affect it in the near future are taken into } \\
\text { account. For segetal habitat it is particularly important to } \\
\text { assess the possibility of further agricultural use }\end{array}$ & $\begin{array}{l}\text { Conservation } \\
\text { prospects for } \\
\text { the habitat } \\
\text { are good or } \\
\text { excellent, no } \\
\text { significant } \\
\text { impact of } \\
\text { threatening } \\
\text { factors } \\
\text { predicted }\end{array}$ & $\begin{array}{l}\text { The real } \\
\text { possibilities } \\
\text { of the impact } \\
\text { of threatening } \\
\text { factors }\end{array}$ & $\begin{array}{l}\text { Conservation } \\
\text { prospects for } \\
\text { the habitat are } \\
\text { bad, strong } \\
\text { impact of } \\
\text { threatening } \\
\text { factors } \\
\text { observed, no } \\
\text { survival of the } \\
\text { habitat can be } \\
\text { guaranteed } \\
\text { in the longer } \\
\text { perspective }\end{array}$ \\
\hline \multicolumn{2}{|c|}{ Overall assessment } & $\begin{array}{l}\text { All parameters } \\
\text { evaluated as } \\
\text { FV }\end{array}$ & $\begin{array}{l}\text { One or more } \\
\text { parameters } \\
\text { evaluated as } \\
\text { U1, no U2 } \\
\text { evaluations }\end{array}$ & $\begin{array}{l}\text { One or more } \\
\text { parameters } \\
\text { evaluated as } \\
\text { U2 }\end{array}$ \\
\hline
\end{tabular}

Explanations: *cardinal index

habitats, which form a mosaic with other habitats, marking a transect of the envisaged dimensions was not possible in a single patch of the habitat, so the places for phytosociological relevés were chosen arbitrarily.
On each chosen site, we took 3 phytosociological relevé samples based on the classical Braun-Blanquet method (Dzwonko 2007) on the standard for nature monitoring plot sizes of 5m x 5m (Mróz 2010, 2012a, 
$2012 b$ ), or smaller, if the habitat covered a small area of the site or its size precluded making a standard phytosociological relevé.

The collected data were recorded on standard forms used for the monitoring of natural habitats (Mróz 2010, 2012a, 2012b). The form consisted of several parts: a natural habitat observation sheet for the monitored location, assessment of the habitat conservation status at the site, a list of current impacts and threats (and future foreseeable impacts), and other information (Bomanowska 2013a, 2013b; Kirpluk 2013a, 2013b).

\subsection{Parameters and indices of conservation status}

The current conservation status ("condition") of the monitored habitats was assessed on the basis of three groups of parameters: $(i)$ surface area of the habitat within the conservation area, (ii) specific structure and functions, (iii) conservation prospects of the habitat. Each of the parameters presents a synthetic description of a group of the characteristics of monitored habitats, as well as factors affecting them (Tables 1-2). Parameters adopted for synanthropic habitats conform to the recommendations in the SEMP and the scale of evaluation was the same as that used in the monitoring of natural habitats: FV - favourable status; U1 - unfavourable, inadequate; U2 - unfavourable, bad (Mróz 2010, 2012a, 2012b).

The way of evaluating the "surface area" and "conservation prospects" parameters is the same for all natural habitats. The "specific structure and functions" parameter describes these features which distinguish a given habitat and decide about its unique nature. Therefore, the indicators included in this parameter were matched individually. The scope and methods of measuring the indices are given in tables (Tables 1-2). Two new indices were introduced, i.e. "archaeophytes" and "anthropogenic pressure". Almost all typical synanthropic communities are formed by archaeophytes, which are often dominant in species composition (Matuszkiewicz 2008; Balcerkiewicz \& Pawlak 2010). A decrease in the share of this group of species may indicate the degeneration of a plant community. The index "anthropogenic pressure" defines the effects of human activity (techniques and intensity of soil cultivation and modes of crop cultivation, level of agro-chemical inputs, and other anthropogenic impact factors) that enable the maintenance of that habitat. A more detailed definition of "alien invasive species" was established because alien species, including invasive ones, are an integral component of synanthropic communities and some of them are characteristic or distinguishing species for syntaxonomic units, such as: Anthoxanthum aristatum, Echinochloa crus-galli, Galinsoga ciliata, G. parviflora, Setaria viridis, S. glauca and Veronica persica (Matuszkiewicz 2008). These are also species considered as invasive in Poland (Tokarska-Guzik et al. 2012). Because of their diagnostic value, their presence in the described communities was not considered as a decrease in the community's value, unless they reached a considerable (over 50\%) cover rate in the monitored location. For segetal habitats, we did not use the commonly used for non-forest habitats index "expansion of shrubs and underwood", because this index provides information on succession in phytocenoses, which in agricultural phytocenoses occurs after farming was abandoned, i.e., when the major factor determining their existence was eliminated.

The following cardinal indices with particular significance for the assessment of the conservation status of discussed habitats were established after the analysis of collected data: typical species, archaeophytes, native expansive species of herbaceous plants (only segetal habitats), anthropogenic pressure (Bomanowska 2013a; Kirpluk 2013a). The values of the used indices for the status of monitored habitats, expressed numerically or descriptively, were evaluated similarly as parameters of the conservation status, on a three-level scale (FV, U1, U2; Tables 1-2).

Because of the adopted methodology (no transect was established) parameters and indices were used for the evaluation of the whole habitat on the site.

Methodological records, with a detailed description of research procedure and reports on the carried out monitoring, including reporting forms for individual sites, maps of monitoring locations prepared in ArcGIS and photographic records, were submitted to the Monitoring Department of Kampinos National Park.

\section{Results}

\subsection{Phytosociological identifiers of monitored habitats}

During field research carried out in the segetal habitats under a monitoring project, we identified six plant communities: two associations and two communities of cereal weeds from the Centauretalia cyani order in winter cereals (rye and triticale), i.e., ArnoseridoScleranthetum, Spergulo-Veronicetum dillenii, community from Aperion spicae-venti alliance, transitional community Arnoserido-Scleranthetum - Papaveretum argemones, and two associations of root crop weeds from the Polygono-Chenopodietalia order formed in potato fields and in garden plants, i.e., EchinochlooSetarietum and Galinsogo-Setarietum.

In the ruderal habitats, five plant communities were identified: two associations of annual and biennial ruderal weeds from the Sisymbrietalia order: Sisymbrietum sophiae and Urtico-Malvetum neglectae, and three associations of perennial nitrophilous weeds from the Artemisienea subclass: Berteroëtum incanae, 
Table 2. Description and evaluation of parameters and indices of the specific structure of the habitat, as well as "conservation prospects" for ruderal habitats in the Kampinos National Park (according to Kirpluk 2013a, amended)

\begin{tabular}{|c|c|c|c|c|}
\hline \multirow[b]{2}{*}{ Parameter/Index } & \multirow[b]{2}{*}{ Description } & \multicolumn{3}{|c|}{ Status } \\
\hline & & $\begin{array}{l}\text { Favourable } \\
\text { (FV) }\end{array}$ & $\begin{array}{l}\text { Unfavourable, } \\
\text { inadequate } \\
\quad(\mathrm{U} 1)\end{array}$ & $\begin{array}{c}\text { Unfavourable, } \\
\text { bad (U2) }\end{array}$ \\
\hline $\begin{array}{l}\text { Parameter } \\
\text { "Surface area of } \\
\text { the habitat" }\end{array}$ & $\begin{array}{l}\text { An assessment of the changes in surface area (stable, } \\
\text { increases or decreases ) occupied by the habitat and its } \\
\text { dynamics is required }\end{array}$ & $\begin{array}{l}\text { Does not } \\
\text { change or } \\
\text { increases }\end{array}$ & $\begin{array}{l}\text { A slight } \\
\text { decrease in the } \\
\text { habitat area in } \\
\text { comparison } \\
\text { with previous } \\
\text { studies or cited } \\
\text { in references }\end{array}$ & $\begin{array}{l}\text { An evident } \\
\text { decrease in the } \\
\text { habitat area in } \\
\text { comparison } \\
\text { with previous } \\
\text { studies or cited } \\
\text { in references }\end{array}$ \\
\hline
\end{tabular}

Parameter "Specific structure and functions"

Spatial structure Determination of the habitat fragmentation level (high, of the habitat medium or low) in the ordering scale and quoting the areas patches of particular habitat patches in the location. The indicator shows the patchiness of the habitat. The well-preserved ruderal habitat is relatively slightly fragmented, although the presence of patches is always determined by local development, presence of roads, etc. Fragmentation of this habitat in KNP mainly results from the dynamics of vegetation associated with change in use, less often with change in edaphic factors, e.g., land overdrying, formation of brushwoods during succession, etc. Only in cases when high fragmentation is associated with the use of area, it can be considered adequate

$\begin{array}{lll}\text { Lacking } & \text { Average } & \text { High } \\ \text { or slight } & \text { fragmentation } & \text { fragmentation } \\ \text { fragmentation } & \text { level } & \text { level }\end{array}$

List of typical species for the habitat includes characteristic and distinguishing species for Artemisienea subclass and its lower syntaxonomic units and for Sisymbrietalia order, Sisymbrion officinalis alliance and their lower syntaxonomic units. A list of typical species with their approximate percentage of coverage (with an accuracy of $10 \%$ ) in the location should be given

\section{Numerous} species

and with

significant

coverage $(3$

or more on

the Braun-

Blanquet

scale)

\section{Dominant}

species
This index describes the structure of plant communities in the monitored location, as well as their conservation status (or, possibly, the degree of their deformation). It answers the question of whether the species characteristic of the habitat dominate in the monitored location. The index describes the presence of co-dominant and dominant species (score 3 or more on the Braun-Blanquet scale). If dominant species are species typical for the habitat, the index is evaluated as adequate. However, if invasive species, trees or shrubs are dominant, the index value is decreased. A list of species dominating in the location and their approximate percentage coverage (with an accuracy of $10 \%$ ) should be given. Only species with the highest coverage in the location $(\geq 10 \%)$ should be replaced

\footnotetext{
*Archaeophytes Index describes the share of archaeophtes, e.g. alien species established in Polish flora, which arrived in "ancient" times (prior to 1492). Typically formed ruderal communities are characterised by a significant share of species from this group. A reduced number of archaeophytes indicates the degeneration of the community and reduces the index value. A list of archaeophytes and their approximate percentage coverage (with an accuracy of $10 \%$ ) should be given
} Numerous $(\geq 5) \quad$ Several (2-5)

Clear reduction No typical in the quantity species or one and coverage of typical species of them with insignificant coverage

\section{Species} characteristic of the habitat dominate, or no dominant present

Clear reduction
in the quantity
and coverage
of typical
species

Among dominants, expansive species or species alien to the habitat in ecological terms are present 


\begin{tabular}{|c|c|c|c|c|}
\hline \multirow[b]{2}{*}{ Parameter/Index } & \multirow[b]{2}{*}{ Description } & \multicolumn{3}{|c|}{ Status } \\
\hline & & $\begin{array}{l}\text { Favourable } \\
\text { (FV) }\end{array}$ & $\begin{array}{l}\text { Unfavourable, } \\
\text { inadequate } \\
\text { (U1) }\end{array}$ & $\begin{array}{l}\text { Unfavourable, } \\
\text { bad (U2) }\end{array}$ \\
\hline $\begin{array}{l}\text { Alien invasive } \\
\text { species }\end{array}$ & $\begin{array}{l}\text { This index describes the degree of deformation of the } \\
\text { habitat and share of geographically alien species considered } \\
\text { as invasive in Poland. The presence of even single } \\
\text { individuals ("+" for quantity on the Braun-Blanquet scale) } \\
\text { should be associated with a decreased index value. Ruderal } \\
\text { communities, despite being formed largely by alien } \\
\text { species, are not characterised by the presence of invasive } \\
\text { species. An exception to this case are phytocenoses of } \\
\text { the Sisymbrietalia order, where alien invasive species are } \\
\text { present. In this case, these species should not be taken } \\
\text { into consideration unless their coverage is significant } \\
\text { (more than } 50 \% \text { ). A list of invasive alien species should be } \\
\text { given together with their percentage proportions (with an } \\
\text { accuracy of } 10 \% \text { ) }\end{array}$ & $\begin{array}{l}\text { No invasive } \\
\text { species and/ } \\
\text { or the total } \\
\text { coverage } \\
\text { of invasive } \\
\text { species } \\
\text { characteristic } \\
\text { for } \\
\text { Sisymbrietalia } \\
<50 \%\end{array}$ & $\begin{array}{l}\text { Single } \\
\text { individuals } \\
\text { of invasive } \\
\text { species } \\
\text { with a total } \\
\text { coverage }<5 \% \\
\text { or coverage } \\
\text { of invasive } \\
\text { species } \\
\text { characteristic } \\
\text { for } \\
\text { Sisymbrietalia } \\
<50 \%\end{array}$ & $\begin{array}{l}\text { Coverage } \\
\text { of invasive } \\
\text { species } \geq 5 \% \\
\text { and/or total } \\
\text { coverage } \\
\text { of invasive } \\
\text { species } \\
\text { characteristic } \\
\text { for } \\
\text { Sisymbrietalia } \\
\geq 50 \%\end{array}$ \\
\hline $\begin{array}{l}\text { Expansion of } \\
\text { shrubs and under } \\
\text { growth }\end{array}$ & $\begin{array}{l}\text { This parameter characterises the threat that the habitat will } \\
\text { be overgrown by shrub formations and forest communities. } \\
\text { The indicator is described by the total coverage of shrubs } \\
\text { and underwood in the location. The described habitat } \\
\text { is found in mosaic systems with other anthropogenic } \\
\text { communities, not considered in the study, and next to } \\
\text { overgrowing meadows and forest communities, so the } \\
\text { encroachment of shrubs and trees is a natural process. } \\
\text { However, if this process is combined with less intensive } \\
\text { agricultural use and even anthropogenic pressure causing } \\
\text { changes, the habitat becomes strongly or completely } \\
\text { degraded. A list of tree and shrub species occurring in the } \\
\text { location should be given together with the approximate } \\
\text { percentage coverage (with an accuracy of } 10 \% \text { ) by each } \\
\text { species and the total coverage by all trees and shrubs }\end{array}$ & $\begin{array}{l}\text { Total coverage } \\
\text { in the location } \\
<1 \%\end{array}$ & $\begin{array}{l}\text { Total coverage } \\
\text { in the location } \\
1-5 \%\end{array}$ & $\begin{array}{l}\text { Total cover in } \\
\text { the location } \\
>5 \%\end{array}$ \\
\hline $\begin{array}{l}\text { *Anthropogenic } \\
\text { pressure }\end{array}$ & $\begin{array}{l}\text { This index describes the effect of human activity } \\
\text { (management and other anthropogenic factors affecting } \\
\text { ruderal habitats) that allow for the preservation of the } \\
\text { habitat }\end{array}$ & $\begin{array}{l}\text { Adequate } \\
\text { (extensive } \\
\text { methods of } \\
\text { management) }\end{array}$ & $\begin{array}{l}\text { Decreased } \\
\text { extensive } \\
\text { management } \\
\text { or increased } \\
\text { effect of other } \\
\text { anthropogenic } \\
\text { factors }\end{array}$ & $\begin{array}{l}\text { Lack of } \\
\text { extensive } \\
\text { management } \\
\text { or other strong } \\
\text { anthropogenic } \\
\text { pressure }\end{array}$ \\
\hline $\begin{array}{l}\text { Habitat surface } \\
\text { area of variable } \\
\text { preservation } \\
\text { status on the site }\end{array}$ & $\begin{array}{l}\text { The index describes the surface area of habitat patches } \\
\text { with a well-preserved species composition. The percentage } \\
\text { share of well-preserved patches should be specified with } \\
\text { respect to those transient, atypical, degraded, including } \\
\text { expansive species, etc. Typical patches are identified with } \\
\text { consideration of the share of species typical for the plant } \\
\text { community }\end{array}$ & $\begin{array}{l}\text { Well-preserved } \\
\text { patches cover } \\
\geq 50 \% \text { of the } \\
\text { site surface } \\
\text { area }\end{array}$ & $\begin{array}{l}\text { Well-preserved } \\
\text { patches } \\
\text { cover }<50 \% \\
\text { of the site } \\
\text { surface area } \\
\text { or generally } \\
\text { patches are not } \\
\text { very typical, } \\
\text { but there are } \\
\text { no poorly } \\
\text { preserved } \\
\text { patches }\end{array}$ & $\begin{array}{l}\text { Well-preserved } \\
\text { patches } \\
\text { cover }<50 \% \\
\text { of the site } \\
\text { surface area } \\
\text { and poorly } \\
\text { preserved } \\
\text { patches are } \\
\text { present }\end{array}$ \\
\hline \multicolumn{2}{|c|}{ Assessment of Parameter "Specific structure and functions" } & $\begin{array}{l}\text { All cardinal } \\
\text { indices } \\
\text { evaluated as } \\
\text { FV, remaining } \\
\text { indices as at } \\
\text { least U1 }\end{array}$ & $\begin{array}{l}\text { One or more } \\
\text { cardinal } \\
\text { indices } \\
\text { evaluated as } \\
\text { U1 }\end{array}$ & $\begin{array}{l}\text { One or more } \\
\text { cardinal } \\
\text { indices } \\
\text { evaluated as } \\
\text { U2 }\end{array}$ \\
\hline
\end{tabular}




\begin{tabular}{|c|c|c|c|c|}
\hline $\begin{array}{l}\text { Parameter } \\
\text { "Conservation } \\
\text { prospects of the } \\
\text { habitat" }\end{array}$ & $\begin{array}{l}\text { Assessment of realistic possibility for the maintenance of } \\
\text { the habitat in an appropriate state, its current conservation } \\
\text { status and factors that can affect it in the near future are } \\
\text { taken into account. For ruderal habitats it is particularly } \\
\text { important to assess the possibility of further extensive use }\end{array}$ & $\begin{array}{l}\text { Conservation } \\
\text { prospects for } \\
\text { the habitat } \\
\text { are good or } \\
\text { excellent, no } \\
\text { significant } \\
\text { impact of } \\
\text { threatening } \\
\text { factors } \\
\text { predicted }\end{array}$ & $\begin{array}{l}\text { The real } \\
\text { possibilities } \\
\text { of impact of } \\
\text { threatening } \\
\text { factors }\end{array}$ & $\begin{array}{l}\text { Conservation } \\
\text { prospects for } \\
\text { the habitat are } \\
\text { bad, strong } \\
\text { impact of } \\
\text { threatening } \\
\text { factors } \\
\text { observed, no } \\
\text { survival of the } \\
\text { habitat can be } \\
\text { guaranteed in } \\
\text { longer time } \\
\text { perspective }\end{array}$ \\
\hline Overall assessment & & $\begin{array}{l}\text { All parameters } \\
\text { evaluated as } \\
\text { FV }\end{array}$ & $\begin{array}{l}\text { One or more } \\
\text { parameters } \\
\text { evaluated as } \\
\mathrm{U} 1 \text {, no U2 } \\
\text { evaluations }\end{array}$ & $\begin{array}{l}\text { One or more } \\
\text { parameters } \\
\text { evaluated as } \\
\mathrm{U} 2\end{array}$ \\
\hline
\end{tabular}

Explanations: *cardinal index

Leonuro-Ballotetum nigrae and Arctio-Artemisietum vulgaris.

3.2. Evaluation of the preservation status of plant communities

The parametric evaluation of the monitored sites provided variable results (Tables 3-4). A reference segetal location was not indicated. Phytocenoses best reflecting the monitored habitat included those of the Arnoserido-Scleranthetum association on the Mariew II site, formed in winter rye, the community from the Aperion spicae-venti alliance identified in household winter rye and triticale on a Józefów site, the Galinsogo-Setarietum association, formed in

Table 3. Evaluation of the conservation status of segetal habitats in the Kampinos National Park

\begin{tabular}{|c|c|c|c|c|}
\hline \multirow[b]{2}{*}{ Monitored location } & \multicolumn{4}{|c|}{ Assessment of the parameter } \\
\hline & $\begin{array}{l}\text { Area of the } \\
\text { habitat }\end{array}$ & $\begin{array}{c}\text { Specific } \\
\text { structure } \\
\text { and } \\
\text { function }\end{array}$ & $\begin{array}{l}\text { Conservation } \\
\text { prospects }\end{array}$ & $\begin{array}{c}\text { Overall } \\
\text { assessment }\end{array}$ \\
\hline Cisowe (Echinochloo-Setarietum; household potato cultivation) & FV & FV & FV & FV \\
\hline Górki (Echinochloo-Setarietum; potato cultivation) & FV & U1 & FV & $\mathrm{U} 1$ \\
\hline $\begin{array}{l}\text { Józefów (community from Aperion spicae-venti alliance; } \\
\text { household winter rye and triticale cultivation) }\end{array}$ & FV & FV & FV & FV \\
\hline Kiścinne (Spergulo-Veronicetum dillenii; winter rye cultivation) & FV & $\mathrm{U} 1$ & FV & $\mathrm{U} 1$ \\
\hline Łubiec (Arnoserido-Scleranthetum; triticale cultivation) & $\mathrm{FV}$ & $\mathrm{U} 1$ & $\mathrm{FV}$ & $\mathrm{U} 1$ \\
\hline $\begin{array}{l}\text { Mariew II (Arnoserido-Scleranthetum; household winter rye } \\
\text { cultivation) }\end{array}$ & FV & FV & FV & FV \\
\hline $\begin{array}{l}\text { Nowa Dąbrowa (Echinochloo-Setarietum; household winter rye } \\
\text { cultivation) }\end{array}$ & $\mathrm{FV}$ & U1 & FV & U1 \\
\hline $\begin{array}{l}\text { Sieraków (Galinsogo-Setarietum; household vegetable } \\
\text { cultivation) }\end{array}$ & FV & U1 & FV & U1 \\
\hline $\begin{array}{l}\text { Stara Dąbrowa (Galinsogo-Setarietum; household potato and } \\
\text { vegetable cultivation) }\end{array}$ & FV & $\mathrm{FV}$ & FV & FV \\
\hline $\begin{array}{l}\text { Wiersze (Arnoserido-Scleranthetum-Papaveretum argemones } \\
\text { community; household winter rye cultivation) }\end{array}$ & $\mathrm{FV}$ & U1 & FV & U1 \\
\hline \multirow{3}{*}{ Total } & $\mathrm{FV}-10$ & $F V-4$ & $\mathrm{FV}-10$ & $F V-4$ \\
\hline & $\mathrm{U} 1-0$ & $\mathrm{U} 1-6$ & $\mathrm{U} 1-0$ & $\mathrm{U} 1-6$ \\
\hline & $\mathrm{U} 2-0$ & $\mathrm{U} 2-0$ & $\mathrm{U} 2-0$ & $\mathrm{U} 2-0$ \\
\hline
\end{tabular}

Explanations: in parentheses - the identified phytosociological unit and the type of segetal habitat (type of crop); the values of the parameters for the status of monitored habitats, FV - favourable status, U1 - unfavourable, inadequate, U2 - unfavourable, bad 
Table 4. Evaluation of the conservation status of ruderal habitats in the Kampinos National Park

\begin{tabular}{|c|c|c|c|c|}
\hline \multirow[b]{2}{*}{ Monitored location } & \multicolumn{4}{|c|}{ Assessment of the parameter } \\
\hline & $\begin{array}{c}\text { Area of the } \\
\text { habitat }\end{array}$ & $\begin{array}{c}\text { Specific } \\
\text { structure } \\
\text { and } \\
\text { function }\end{array}$ & $\begin{array}{l}\text { Conservation } \\
\text { prospects }\end{array}$ & $\begin{array}{c}\text { Overall } \\
\text { assessment }\end{array}$ \\
\hline $\begin{array}{l}\text { Buda (Leonuro-Ballotetum nigrae) near cottage and building } \\
\text { foundations }\end{array}$ & FV & U1 & $\mathrm{U} 1$ & U1 \\
\hline $\begin{array}{l}\text { Granica (Leonuro-Ballotetum nigrae; Urtico-Malvetum } \\
\text { neglectae) cottage yard: near cottage and fence }\end{array}$ & U1 & U1 & U1 & U1 \\
\hline $\begin{array}{l}\text { Józefów I (Arctio-Artemisietum vulgaris) cottage yard: near } \\
\text { cottage and fence }\end{array}$ & $\mathrm{FV}$ & FV & FV & FV \\
\hline $\begin{array}{l}\text { Józefów II (Sisymbrietum sophiae; Urtico-Malvetum } \\
\text { neglectae) cottage yard: near fence }\end{array}$ & U1 & U1 & U1 & U1 \\
\hline $\begin{array}{l}\text { Rybitew I (Arctio-Artemisietum vulgaris, Leonuro-Ballotetum } \\
\text { nigrae) cottage yard: near cottage }\end{array}$ & FV & FV & U1 & U1 \\
\hline Rybitew II (Arctio-Artemisietum vulgaris) roadside & U1 & $\mathrm{U} 1$ & $\mathrm{U} 1$ & $\mathrm{U} 1$ \\
\hline $\begin{array}{l}\text { Sieraków (Urtico-Malvetum neglectae) cottage yard: near } \\
\text { cottage }\end{array}$ & U1 & FV & FV & $\mathrm{U} 1$ \\
\hline Zamość I (Leonuro-Ballotetum nigrae) near cottage & U1 & FV & FV & U1 \\
\hline $\begin{array}{l}\text { Zamość II (Leonuro-Ballotetum nigrae) cottage yard: near } \\
\text { cottage }\end{array}$ & U1 & U1 & $\mathrm{U} 1$ & $\mathrm{U} 1$ \\
\hline Zamość III (Berteroetum incanae) roadside & U1 & U1 & U1 & U1 \\
\hline Total & $\begin{array}{l}\mathrm{FV}-3 \\
\mathrm{U} 1-7 \\
\mathrm{U} 2-0\end{array}$ & $\begin{array}{l}\mathrm{FV}-7 \\
\mathrm{U} 1-3 \\
\mathrm{U} 2-0\end{array}$ & $\begin{array}{l}\mathrm{FV}-4 \\
\mathrm{U} 1-6 \\
\mathrm{U} 2-0\end{array}$ & $\begin{array}{l}\mathrm{FV}-1 \\
\mathrm{U} 1-9 \\
\mathrm{U} 2-0\end{array}$ \\
\hline
\end{tabular}

Explanations: in parentheses - the identified phytosociological unit and the type of ruderal habitat; parameter values for the status of monitored habitats, FV - favourable status, U1 - unfavourable, inadequate, U2 - unfavourable, bad

household vegetable and potato cultivation on a site in Stara Dąbrowa, and the Echinochloo-Setarietum association in household potato cultivation on a site in Cisowe (Table 3). In all these sites, all the indices describing the plant community indicated its favourable status. On the other six sites, the overall evaluation was unfavourable (Table 3). Lower scores of the evaluation in three cases (sites: Górki, Nowa Dąbrowa and Sieraków) were attributed to the presence of invasive species, inadequate value of a parameter regarding "specific structure and functions", reduced by incorrect agricultural technique on two monitored sites (Kiścinne and Wiersze), and the presence of both these factors on one site (Łubiec).

For ruderal habitats, all the indices describing plant communities were evaluated positively only in one case and only one reference ruderal site, i.e. the ArctioArtemisietum vulgaris association on the Józefów I site was indicated. Other well-preserved communities were the Urtico-Malvetum neglectae association on a site in Sieraków and the Leonuro-Ballotetum nigrae association on the Zamość I site (Table 4). On the other eight sites, the parametric evaluation of the habitat provided variable results and the status of ruderal communities was inadequate. This evaluation of preservation status for ruderal habitats in the villages of Kampinos region was mostly affected by two indices: surface area of the habitat and spatial structure of vegetation patches (in most cases evaluated as U1 unfavourable, inadequate). The patches of well-preserved ruderal habitats are difficult to distinguish and have very small surface areas, because cottages and their surroundings are no longer typical farms and are owned by private owners, so access to them is restricted. The evaluation was negatively affected by the index 'invasive species', which only in one case (Sieraków site) was evaluated as adequate.

\subsection{Evaluation of influencing factors}

We indicated the major factors influencing communities which are important today and may potentially pose a threat to the survival of the monitored habitats. The analysis of data collected during the monitoring revealed that the main threats to synanthropic habitats in KNP are: cessation of use - cessation of farming initiates secondary succession on segetal habitats, depopulation 
of households and demolition of buildings, followed by ploughing, which destroys ruderal habitats irreversibly. One serious threat to segetal habitats is the replacement of organic fertilizers with mineral ones (mostly artificial nitrogen fertilizers) and the increased use of chemicals for plant protection (authors' personal observations and information obtained from the owners during the monitoring studies), which causes the degradation of agricultural habitats.

The persistence of ruderal communities near cottages, fences, rubbish heaps, etc., is threatened by changes in the use of cottages and the lack of typical rural yards. Most cottage yards are very neat, surrounded with concrete or metal fencing, often paved, and the owners of cottages do not keep farm animals anymore, even chickens or other poultry that could walk around the property. In many places organic waste is not dumped anymore, or rubbish heaps no longer exist. This limits the supply of nutrients, particularly nitrogen, to the soil, which disables the persistence of nitrophilous ruderal communities. On the roadsides, ruderal communities are often threatened by frequent mowing, which leads to the dominance of grasses in ruderal habitats and the withdrawal of some other species (authors' personal observations).

The invasion of alien species is a negative factor for both types of communities. This mainly refers to Acer negundo, Echinocystis lobata, Robinia pseudoacacia and Solidago gigantea.

\section{Discussion}

\subsection{Benefits and limitations of the implemented monitoring}

As shown above, with the use of methodology compliant with the recommendations of SEMP, we were able to obtain detailed information on the current status of synanthropic habitats allowing the evaluation of their conservation status, threats and conservation prospects. The collected data allow counteracting the observed negative changes and taking up specific conservation measures.

The focus on detailed aspects during the monitoring study also allowed us to evaluate the preservation status of individual synanthropic species, including the identification of new sites of species endangered in Poland, such as Asperugo procumbens (E; Zarzycki \& Szelag 2006), and species valuable for the area of KNP, such as: Arnoseris minima and Malva pusilla (Kirpluk \& Bomanowska 2008).

Developing and applying a uniform organisationalmethodological system of monitoring for the discussed habitats enables us to link the monitoring of the conservation status of synanthropic habitats with the monitoring of natural habitats in KNP.
The appropriate interpretation of results requires additional information about synanthropic habitats, regarding, for example, carried out agrotechnical practices - their intensity and type, weed control methods, use of chemicals for the protection of crops, fertilization of arable fields, and also potential changes in the type of use on the monitored sites in the future. Such additional information could be obtained from land owners in direct conversation, or based on a brief interview using a short questionnaire.

However, the most important factor distinguishing this type of nature monitoring from the monitoring of natural habitats, and at the same time limiting the actual possibility of carrying out field research, was the fact that almost all synanthropic habitats are located on privately owned land. Owners' permission is always required to carry out research, and it cannot be obtained in all cases. Therefore, it is important to arrange the study site with a local forester, who might provide great assistance in searching for suitable sites, and in negotiations with local people. Research was carried out in selected places, agreed with the land owners and indicated by the Forestry Service of Kampinos National Park. This, beyond any doubt, affects the value of the monitored habitats.

The locations chosen for monitoring should be suitable for repeated research on the same sites (Mróz 2010, 2012a, 2012b). Monitoring means maintaining regular surveillance by making measurements at regular time intervals over an indefinite, usually long, period of time. The length of time is fundamental to the design and purpose of all nature monitoring programmes (Vaughan et al. 2001; Legg \& Nagy 2006; Lindenmayer \& Likens 2009). For this reason, in some cases, despite available permission for observations, the monitoring was abandoned because land owners provided information about the changes in habitat use or plans for its total destruction in the near future. Therefore, our choice was focused on the places where segetal and ruderal habitats in KNP are still identifiable and where there is a chance for their preservation.

Monitoring was carried out in all potentially accessible locations of the habitat because of its limited acreage in the KNP, high dynamics, and threats posed by natural (secondary succession) and anthropogenic factors (change in land use, including purposeful actions of the park administration). Therefore, pilot field research was necessary, after which locations best representing the preservation status of the habitat in this area were chosen.

Unfortunately, because the monitoring sites are located on privately owned arable fields, it is very difficult to limit the negative effects of the factors we identified, similarly like the implementation and enforcement of the active methods of protection. 


\subsection{Recommendations and prospects}

Despite the existing limitations, the evaluation of the conservation status of synanthropic habitats based on the results of monitoring of the sites should be continued in the future in the area of KNP, and, whenever possible, implemented in other protected areas. It can be implemented in national parks where, as in KNP, synanthropic habitats are a permanent element of nature and landscape (e.g., Wielkopolska NP or Narew NP).

The developed and implemented methodology designed according to SEMP are useful for synanthropic habitats, although the guidelines should not be applied automatically, but instead treated as a 'conceptual framework', and the planning of conservation for such habitats should also involve other concepts.
Ruderal and segetal habitats cannot be analysed jointly, as these habitats differ in terms of characteristic species. Because of the significant threats to habitat status, and the rapid changes that are taking place in KNP, monitoring research should be repeated in a 2-3-year cycle.

Importantly, this is the first proposal for the standardized monitoring of synanthropic habitats, and, thus, it will be revised in future in line with further experience and new findings.

Acknowledgments. We wish to cordially thank the staff of KNP, particularly the Forestry Service, for their invaluable help in field research, and Dr Marcin Kiedrzyński (University of Łódź) for the preparation of vector maps in ArcGIS. We would also like to thank Mrs Jolanta Aleksandruk-Foulds for translating this work into English and linguistic corrections. We thank the anonymous reviewer for valuable comments and suggestions on the manuscript.

\section{References}

ACt of 20 June 1991 ON THE InSPECTION FOR ENVIRONMENTAL Protection. Journal of Laws of 2007 No 44, item 287, with later amendments.

AndrzejewsKa A. 2003. Physiography and nature monitoring of the Kampinoski National Park and its buffer zone. Ecohydrology and Hydrobiology 3: 247-254.

Balcerkiewicz S. \& PawlaK G. 2010. Rola gatunków obcych w zbiorowiskach segetalnych Polski. Fragm. Agronom. 27(2): 19-30.

BeEver E. A. 2006. Monitoring biological diversity: strategies, tools, limitations, and challenges. Northwestern Naturalist 87: 66-79.

BOMANOWSKA A. 2006. Importance of segetal habitat preservation for the biodiversity of Kampinos National Park. Pol. Bot. Stud. 22: 45-52.

Bomanowska A. 2009. Rośliny towarzyszące dawnym uprawom - flora segetalna. In: D. MichALSKA-HEJDUK \& A. Bomanowska (eds.). Rola Kampinoskiego Parku Narodowego w zachowaniu różnorodności biologicznej i krajobrazowej dawnych obszarów wiejskich, pp. 55-67. Kampinoski Park Narodowy, Łódź-Izabelin.

Bomanowska A. 2010. Threat to arable weeds in Poland in the light of national and regional red lists. Plant Breed. Seed Sci. 61(1): 55-74. DOI: 10.2478/v10129010-0013-7

Bomanowska A. 2013a. Zbiorowiska segetalne z klasy Stellarietea mediae w Kampinoskim Parku Narodowym. Metodyka badań monitoringowych, pp. 16. + 5 fotografii. Maszynopis, Kampinoski Park Narodowy.

Bomanowska A. 2013b. Zbiorowiska segetalne z klasy Stellarietea mediae w Kampinoskim Parku Narodowym. Wyniki monitoringu zerowego w roku 2013, pp. $7+42+5$ tabel +29 fotografii +11 map. Maszynopis, Kampinoski Park Narodowy.
Brzeg A. \& Wojterska M. 2001. Zespoły roślinne Wielkopolski, ich stan poznania i zagrożenie. In: M. WoJTERska (ed.). Szata roślinna Wielkopolski i Pojezierza Południowopomorskiego. Przewodnik sesji terenowych 52. Zjazdu PTB, pp. 39-110. Bogucki Wyd. Nauk., Poznań.

Buckland S. T., Magurran A. E., Green R. E. \& Fewster R. M. 2005. Monitoring change in biodiversity through composite indices. Phil. Trans. R. Soc. B 360: $243-$ 254. doi:10.1098/rstb.2004.1589

Cierlik G. 2010. Monitoring stanu ochrony gatunków i siedlisk przyrodniczych - Państwowy Monitoring Środowiska. Studia i Materiały CEPL 12, 2(25): 136-145.

CBD 1992. Convention on Biological Diversity. Secretariat of the Convention on Biological Diversity. 2003. Handbook of the convention on biological diversity. 2nd edition. Secretariat of the Convention on Biological Diversity, Montreal.

Council of the European Communities. 1992. Council Directive 92/43/EEC of 21 May 1992 on the conservation of natural habitats and of wild fauna and flora. Official Journal of the European Communities, series L, 206: 750 .

Critchley C. N. R., Burke M. J. W. \& Stevens D. P. 2003. Conservation of lowland semi-natural grasslands in the UK: a review of botanical monitoring results from agri-environment schemes. Biological Conservation 115: 263-278. doi:10.1016/S0006-3207(03)00146-0

Dzwonko Z. 2007. Przewodnik do badań fitosocjologicznych. In: J. B. FALIŃski (ed.). Vademecum Geobotanicum, 304 pp. Sorus, Instytut Botaniki Uniwersytetu Jagiellońskiego, Poznań-Kraków.

Elzinga C., Salzer D. \& Willoughby J. 1998. Measuring and monitoring plant populations. 496 pp. U.S. De- 
partment of the Interior Bureau of Land Management, Denver, Colorado.

European Commission 1979. Council Directive 79/409/EEC on the conservation of Wild Birds. EC, Brussels.

Green R. E., Balmford A., Crane P. R., Mace G. M., ReynOLDS J. D. \& TURNER R. K. 2005. A framework for improved monitoring of biodiversity: responses to the world summit on sustainable development. Conservation Biology 19: 56-65.

Henry P.-Y., Lengyel Sz., Nowicki P., Julliard R., Clobert J., Čelik T., Gruber B., Schmeller D. S., Babij V. \& HeNLE K. 2008. Integrating ongoing biodiversity monitoring: potential benefits and methods. Biodivers. Conserv. 17: 3357-3382. DOI 10.1007/s10531-0089417-1

Karwowski K. 2003. Monitoring środowiska w Pienińskim Parku Narodowym. Pieniny - Przyroda i Człowiek 8: 119-125.

KĘBŁowsKa A. 2009. Historia osadnictwa. In: D. MichalsKaHejduk \& A. BomanowsKa (eds.). Rola Kampinoskiego Parku Narodowego w zachowaniu różnorodności biologicznej i krajobrazowej dawnych obszarów wiejskich, pp. 9-21. Kampinoski Park Narodowy, Łódź-Izabelin.

KiRPLUK I. 2005. Changes of the ruderal flora of five selected villages in Kampinos National Park (Poland). Thaiszia. J. Botany. 15, Suppl. 1: 255-261.

KIRPLUK I. 2009. Rośliny dawnych osad i przydroży - flora ruderalna. In: D. Michalska-Hejduk \& A. BomanowsKA (red.). Rola Kampinoskiego Parku Narodowego W zachowaniu różnorodności biologicznej i krajobrazowej dawnych obszarów wiejskich, pp. 67-77. Kampinoski Park Narodowy, Łódź-Izabelin.

KIRPLUK I. 2011. Najstarsi przybysze we florze ruderalnej opuszczanych wsi Kampinoskiego Parku Narodowego. Acta Botanica Silesiaca 7: 97-112.

KIRPLUK I. 2013a. Zbiorowiska ruderalne terenów wiejskich Kampinoskiego Parku Narodowego. Metodyka badań monitoringowych, pp. $18+2$ fotografie. Maszynopis, Kampinoski Park Narodowy.

KIRPLUK I. 2013b. Zbiorowiska ruderalne terenów wiejskich Kampinoskiego Parku Narodowego. Wyniki monitoringu zerowego w roku 2013, pp. $10+55+2$ tabele +30 fotografii +11 map. Maszynopis, Kampinoski Park Narodowy.

KirPluK I. \& BomanowsKa A. 2008. Rare, endangered and protected plant species of synanthropic flora of the Kampinos National Park (Central Poland). Biodiv. Res. Conserv. 11-12: 71-80.

KNAPIK R. \& RAJ A. 2014. Monitoring przyrodniczy w Karkonoskim Parku Narodowym jako narzędzie do śledzenia zmian w środowisku. Peckiana 9: 39-44.

LegG C. J. \& NAGy L. 2006. Why most conservation monitoring is, but need not be, a waste of time. Journal of Environmental Management 78: 194-199. doi: 10.1016/j.jenvman.2005.04.016

Lengyel Sz., Kobler A., Kutnar L., Framstad E., Henry P.-Y., Babij V., Gruber B., Schmeller D. \& Henle K. 2008. A review and a framework for the integration of biodiversity monitoring at the habitat level.
Biodivers. Conserv. 17:3341-3356. doi: 10.1007/ s10531-008-9359-7

Lindenmayer D. B. \& Likens G. E. 2009. Adaptive monitoring: a new paradigm for long-term research and monitoring. Trends Ecol. Evol. 24(9): 482-486. doi:10.1016/j.tree.2009.03.005

Makomaska-Juchiewicz M. (ed.) 2010. Monitoring gatunków zwierząt. Przewodnik metodyczny. Część I. 408 pp. Główny Inspektorat Ochrony Środowiska, Warszawa.

Makomaska-Juchiewicz M. \& Baran P. (eds.). 2012a. Monitoring gatunków zwierząt. Przewodnik metodyczny. Część II. 519 pp. Główny Inspektorat Ochrony Środowiska, Warszawa.

Makomaska-Juchiewicz M. \& Baran P. (eds.). 2012b. Monitoring gatunków zwierząt. Przewodnik metodyczny. Część III. 748 pp. Główny Inspektorat Ochrony Środowiska, Warszawa.

Markowski M. 2009. Użytkowanie terenów wiejskich dawniej i dziś. In: D. Michalska-Hejduk \& A. BoMANOwsKa (eds.). Rola Kampinoskiego Parku Narodowego w zachowaniu różnorodności biologicznej i krajobrazowej dawnych obszarów wiejskich, pp. 21-30. Kampinoski Park Narodowy, Łódź-Izabelin.

Matuszkiewicz W. 2008. Przewodnik do oznaczania zbiorowisk roślinnych Polski. In: J. B. FALIŃSKI (ed.). Vademecum Geobotanicum 3, 537 pp. Wyd. Nauk. PWN, Warszawa.

Mirek Z., PięKoŚ-Mirkowa H., Zając A. \& Zając M. 2002. Flowering plants and pteridophytes of Poland. A checklist. In: Z. MireK (ed.). Biodiversity of Poland, 1, 442 pp. W. Szafer Institute of Botany, Polish Academy of Sciences, Kraków.

Mróz W. (ed.). 2010. Monitoring siedlisk przyrodniczych. Przewodnik metodyczny. Cz I. 311 pp. Główny Inspektorat Ochrony Środowiska, Warszawa.

Mróz W. (ed.). 2012a. Monitoring siedlisk przyrodniczych. Przewodnik metodyczny. Część II. 320 pp. Główny Inspektorat Ochrony Środowiska, Warszawa.

Mróz W. (ed.). 2012b. Monitoring siedlisk przyrodniczych. Przewodnik metodyczny. Część III. 338 pp. Główny Inspektorat Ochrony Środowiska, Warszawa.

Nature Conservation Act. Journal of Laws of 2004, No. 92, item 880 with later amendments.

Nichols J. D. \& Williams B. K. 2006. Monitoring for conservation. Trends Ecol. Evol. 21(12): 668-673. doi:10.1016/j.tree.2006.08.007

Niemelä J. 2000. Biodiversity monitoring for decision making. Ann. Zool. Fennici 37: 307-317.

Ostermann O. P. 1998. The need for management of nature conservation sites designated under Natura 2000. J. Appl. Ecol. 35: 968-973.

Parr T. W., Ferretti M., Simpson I. C., Forsius M. \& KovÁCs-LÁNg E. 2002. Towards a long-term integrated monitoring programme in Europe: network design in theory and practice. Environmental Monitoring and Assessment 78: 253-290.

Pereira H. M. \& Cooper H. D. 2006. Towards the global monitoring of biodiversity change. Trends Ecol. Evol. 21 (3): 123-129. doi:10.1016/j.tree.2005.10.015 
PerzanowsKa J. (ed.). 2010. Monitoring gatunków roślin. Przewodnik metodyczny. Cz. I. 256 pp. Główny Inspektorat Ochrony Środowiska, Warszawa.

Perzanowska J. (ed.). 2012a. Monitoring gatunków roślin. Przewodnik metodyczny. Część II. 342 pp. Główny Inspektorat Ochrony Środowiska, Warszawa.

Perzanowska J. (ed.) 2012b. Monitoring gatunków roślin. Przewodnik metodyczny. Część III. 268 pp. Główny Inspektorat Ochrony Środowiska, Warszawa.

RATYŃSKA H. \& BORATYŃSKi A. 2000. Czynna ochrona roślin i zbiorowisk segetalnych i ruderalnych. Przegląd Przyrodniczy 11(2-3): 43-56.

Siciński J. \& SieradZKi J. 2010. Protection of segetal flora and vegetation in Poland (historical outline). Plant Breed. Seed Sci. 61(1): 123-131. DOI: 10.2478/v 10129-010-0019-1

Stem C., Margoluis R., Salafsky N. \& Brown M. 2005. Monitoring and evaluation in conservation: a review of trends and approaches. Conservation Biology 19: 295-309.

Stoate C., Boatman N. D., Borralho R. J., Rio Carvalho C., De SNOo G. R. \& Eden P. 2001. Ecological impacts of arable intensification in Europe. Journal of Environmental Management 63: 337-365. doi:10.1006/ jema.2001.0473

Storkey J., Meyer S., Still K.S. \& Leuschner C. 2012. The impact of agricultural intensification and land-use change on the European arable flora. Proc. Roy. Soc. B 279: 1421-1429. doi:10.1098/rspb.2011.1686

Teder T., Moora M., Roosaluste E., Zobel K., Pärtel M., KõLJALG U. \& ZoBel M. 2007. Monitoring of biological diversity: a common-ground approach. Conservation Biology 21: 313-317.
TOKARSKa-GuZiK B., DAJdoK Z., Zając M., ZająC A., URBisz A., Danielewicz W. \& Holdyński Cz. 2012. Rośliny obcego pochodzenia w Polsce ze szczególnym uwzględnieniem gatunków inwazyjnych. 197 pp. Generalna Dyrekcja Ochrony Środowiska, Warszawa.

Vaughan H., Brydges T., Fenech A. \& Lumb A. 2001. Monitoring long-term ecological changes through the ecological monitoring and assessment network: science-based and policy relevant. Environmental Monitoring and Assessment 67: 3-28.

Vos P., Meelis E. \& Ter Keurs W. J. 2000. A framework for the design of ecological monitoring programs as a tool for environmental and nature management. Environmental Monitoring and Assessment 61: 317-344.

Weber D., Hintermann U. \& Zangger A. 2004. Scale and trends in species richness: considerations for monitoring biological diversity for political purposes. Global Ecol. Biogeogr. 13: 97-104.

Yoccoz N. G., James D. Nichols J. D. \& Boulinier T. 2001. Monitoring of biological diversity in space and time. Trends Ecol. Evol.16: 446-453. doi:10.1016/S01695347(01)02205-4

ZAJĄC M. \& ZAJĄC A. 2014. Survival problems of archaeophytes in the Polish flora. Biodiv. Res. Conserv. 35: 47-56. DOI 10.2478/biorc-2014-0015

ZARZYCKI K. \& SZELĄG Z. 2006. Red list of the vascular plants in Poland. In: Z. MireK, K. ZARZycki, W. WojewodA \& Z. SzeląG (eds.). Red list of plants and fungi in Poland, pp. 9-20. W. Szafer Institute of Botany, Polish Academy of Sciences, Kraków. 